物理探查の最近の進歩

\author{
飯田波事*

\section{Recent Developments in Geophysical Exploration}

by

\author{
Kumizi IIDA
}

(Résumé)

The recent developments in geophysical exploration all through the world are shortly reviewed.

The subjects in this paper are the following: 1. Introduction. 2. Geophysical exploration in coal fields. 3. Geophysical exploration in oil and gas fields. 4. Geophysical exploration in mining. 5. Enginsering geophysical exploration such as underground water, dam-sites, etc.

Petroleum exoloration geophysics in the United States of America have been sweepingly developed, while coal exploration geophysics as well as mining and engineering geophysics in Japan have comparatively advanced.

\section{1. 緒 带}

物理探查は，欧米各国の久ならずわが国に物いても， ここ数年間に目覚しい進步をとげたといらことができよ 5。物理探査の忘用範囲が执大されたことと，との分解 能が著しく高められてきたこととによって，極めて利用 性が增大した。応用の対象となっている゙ものは金属・非 金属・石㞸・石油・天然ガス等の地下資源やダム・トン ネル・橋梁等土木関係や徤造物の基盤・地下水・温泉・ 地熱・地沪や地震等の災害対策上の地盤, 埋没資材, 具 塚や古垻等の各方面に扣よんでいる。すた地質棈造解明 の点に招いては，調查目的により，また現場の条件によ っていろいろ異なるが, 大は主要構造より小は微細構造 に至る屯で求められて扣り，幾多の資料が蓄積し，業績 も挙げられた。わが国の物理探査の5ち, 特に炭田・油 田・鉱山・地下水・基盤等に招けるるのは，近年著しく 発展し多くの成果を呿さめた。それがため最近, 鈗業・ 土木事業等各種の業界に扔いては物理探査の施設を新た に備えるものが増加 ${ }^{1)} し$, 自ら進んで調查研究を行らよ らな傾向にある。

今回, 物理探查の進歩に関して, 集められた最近の若 干の資料からわが国扣よび諸外国についてその概要を述 ベてみねいと思ら。

* 地質調查所物理探查部部长 地学䧴誌 VoI. 61, No. 4 (686) 1952

1 ) 飯田 没事：物理探鉱第 4 巻第 3 号 (1951)

\section{2. 炭田における物理探查}

わが国に特いては，1933年頔から始められた炭田の物 理探查は，最近にいたり探鉱器の進歩と相まって著しく 発展した。探鉣法の主体は地震法であるが，電気探査も 若干行われている。1949年以前は主として屈折法のみに よって成果を挙げていたが，ここ 2,3 年来反射法をも 併用し, 従来困難視されていた地域の複雑な構造探査に も成功し, 利用範囲が大いに拉大された。1950年に行わ

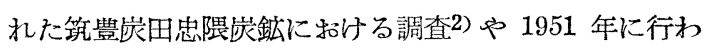
れた筑後川下流地域の調査 3 は，その代表的なるのです ろ5。前者は断層扣よび基盤・㞸層の深度等を推定して 石炭の賦存状態を明らかにしたが，これをとの後実施し た試錐により確認して, 多量に扣よぶ埋蔵炭量をつかみ 得たし, 後者は反射地震計の応用によって初動のほか, 第 2 動, 第 3 動等の波動の検出に成功して, 微細な構造 の解折を可能ならしめ, 結果の精度の向上をはかり炭田 構造を明らかにした。

わが国の炭田は海底に延びているものが多く，したが って, 热查技術もまた海上の特種性に即している必要性 から, その方面の研究が進められ, ここは浮游移動法や 海底曳航法等の探鉣法4) を新たに考察するに至った。こ

2）栗原重利技官等の 1950 年の調查に上る。

3 ) 栗原 重利・䗷川親治技官等の 1952 年の調查に よる。

4) 飯田 汲事・栗原 重利: 物理探鉱第 4 巻第 1 号 (1951) 
れらの方法は極めて高能率で, 彷来の数倍 (1日に数 $\mathrm{km}$ の調査可能）にも達寸るし，また精度も著しく向上され ている。この方法による宇部海底炭田成果は特に注目に 値する。

電気探査は既に亚炭田や無煙炭田の調査に応用された が, 最近海底の断層調査や陸上に特いて地層の追跡に応 用され，ある程度の好結果を得ているよらであるが，今 後の研究に期待がかけられている。な扣炭田地域に扣る 坑井内の探查や一般的構造の探査に，磁気法や重力法が 応用されて成果の挙る日も遠くはをるまい。

炭田に招ける物理探査の成果を総括的5)に考察すれ ば，炭田構造の解明につきるが，第四系の厚さ，第四系 と第三系との区別, 基盤屯での梁度, 基盤上面の形体, 場合により第三系中の細分, 地層の傾斜の緩急, 背斜・ 向斜の構造, 断層, その他の探查加可能となっている。 諸外国に打ける最近の炭田の物理探鉣6)をみるに，ま ず印度に颃いては電気此抵抗法により, 断層や目的とす る地層の深度を求めて, 炭田構造を明らかにしている。 中部のカンプチー炭田地带やアーケエアン地域に抬いて 成果があげられている。米国では，インディアナ州に招 いて, 地震屈折法により地表堆積物の厚さを公範囲にわ たって決定し, 炭田の開発に寄与し, 屯た無煙炭や亜炭 の探査に比抵抗法や重力法を応用して成功している。べ ルギーではベルギァン・カンピン地带の㞸田地域で地震 探鉱の成果を報じている。これは白献紀以前の垂直に近 い断層によって囲ま狄ている区域の水平的拡がりを決定 するために行われたが，この地带の上部には約 $600 \mathrm{~m} に$ も文ぶ 2 次的な第三紀の厚い堆積物が女るよ 5 な構造の ところである。スペインに招いても, 地震探鉣屈折法に より, 重要な炭田地带に顷いて探査が行われ, 良好な成 果が挙げられている。

\section{3. 油田における物理探查}

わが国に招いては, 油田の探査に地震・重力・電気・ 磁気・放射能・地化学等の方法が用いられているが, 特 に, 戦後に特いて米国の寸ぐれた技術を導入し, 最新の 区射地震計扣よび重力計を輸入して探査技術の進歩をは かった結果，わが国に招いて子多分に困難視されていた 反射法による油田構造の探查に劃期的な進歩が見られる にいたった。最近行ったものに茨城県に扣ける反射法の 研究7) があり, また北海道石狩平野8) ・秋田県能代平野

5 ）飯田 没事：炭田探査審議会報告 (1952)

6 ) L. Scharon: Mining Engineering, Feb. (1952)

7 ) 金于徽一・村岡秀記・南雲昭三郎技官等の 1952 年の調查による。

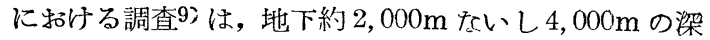
所からの反射波をも明膫に検出できて, 油田構造を明ら かにした。

重力計による調查は従来の重力偏差計による調查を一 新し, 調査能率を著しく向上した。をた新しい結果解析 法として2次微分法の忘用により，地下浅所の局所的小 構造を浮出させることに成功し, 著しく進展をみせた。 北海道石狩・関東・新潟・秋田等の平野に招いて好結果 を得ている。

放射能探查はラドン計による調查からガイガー計数猿 置による の判定等に利用性を拡大していふ。地化学操查はガス田 の調查に大いに成果を挙げた。これは地下水中に溶存し ているガスの分析を考究する地下水法10) の確立により 著しく発展し, 水中メタン量を簡便に定量しろる携带用 小型の器械も考案されて, 告用化されたためにもよるで

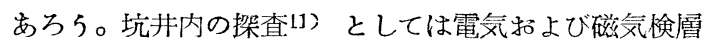
法が進歩した。マイクロロッギングの研究も大いに発展 した。探鉱器としては，12成分反射用地震探鉱器力浣成 され，実用に供されるにいたった。

諸外国に括ける油田の物理探鉱をみるに，屯ず米国に 扣いてはその規模の点や進歩の点に括いて他国の追従を 許さたいところであり, 地震・重力・磁気・電気・放射 能等の各種の方法がそれぞれ応用されて，すぐれた幾多 の業績が挙げられている。1951年に括いては約 600其の 地震探鈗班と約 80 班の重力探鈗班が活動しているし, 約 2 億ドルの経費が石油鉱業の物理挆鉱に使用されてい る。そしてテキサス・オクラホマ・ルイジアナ・カリフ オルニア・ワイオミン等の各州に捺いて新しい、油田が続 々と発見されて物り，新たに発見された石油の埋蔵量は 䄪 22 億 4 千万バーレルにも達しているとのことであ る12》。1947年～1951年の平均として各種探鉱の成功率13) が挙げられているが，それによると

乱掘探鉱 $1 / 20$ 地質探鉱 $1 / 10$ 物理探鉱 $1 / 6$ 地筫 抢よび物理探鉱の併用 $1 / \check{J}$

となっている。米国の物理探鉱は成年の域に達し，もは や“game”ではなくて“business”であるといわれ ている。この陰には間断なく続けられる研究と物し及た くつぎ䢋ま机方研究費とがあるが，いまな扔一層盛んで

8 ）金子・村岡技官等の 1952 年の調查による.

9 ）帝国石油会社の 1952 年の調查に上る。林課長談 とよる。

10）藤原健一・下河原達哉：石油技術協会誌第 13 巻 第 4 号 (1948)

11）渒田隆門：石油技術说会誌第 17 卷第 5 号 (1952)

12), 13) S. Hammer: Geophysics, Vol.17, No. 3, (1952) 
女る。民閒石油会社や物理探鉱專間の会社の充実した研 究所は実に驚くべきもので，1950年筆者がみて来た当時 の事情14) から推察しても想像にあまりがある。その 1 , 2 の例を挙げると, まずガルフ石油会社の研究所には物 理探鈗関係では物理調查部々物理探鈗研究部の 2 部があ り, 研究沂全体の約 2 分の 1 をしめ, 人客約 800 人を上 5して, 近代的設備の研究室と工作工場の下で, 研究と 調査に専念している。水中用地震計・重力計・航空磁力 計・ショーランの装置等優秀な計器の考察装作と波動に 関する基碟的研究や，重力・磁気法に関寸る新解析法の 発見などが特に注目されるるのである。、グノ、リア石油 会社の研究所には, 探查用計器全般の研究・製作・試験 扣上び岩石の密度や带磁率の測定などを行5人員約 300 人の物理架鉱研究所と, 人員約 230 人を有し主として新 技術の研究を担当する野外技術研究所がある。この野外 技術研究所に扔いては, 地震・電気・坑井内物探・地化 学・地啠・掘さく泥 水・油慒工学・熱力学・油井計測 器・現場技術の11部があるが，このらち物理探鉱関係は 約 40 パー七ントをしめ, $\mathrm{M}_{2}$ 波の発生伝播, 電気衝激 波の地下透過等に関寸る基礎的研究や波動生成装置 - 精 密バロメーター・水中カメラ・精密坑井内検層器等の研 究が行われていた。な和土壤の放射能関する研究もか なり進んでいた。以上のほか極めて多くの研究所はある が，いずれる優秀な技術者を多数かかえて理論ならびに 実験的研究を行い,物理操鉣技術の進步に貢献している。

最近の進歩になるるのを挙げれば, 航空機による磁気 および放射能探查・地震波速度の新決定法・地下重力の 測定沠・磁気テープを用いる地震記䩮法・地震波速度検

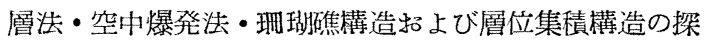
查法・航空磁気怙よび重力探查の新解析法・地震探釷反 射法の解折器械等極めて多い。探鉱器の進歩には航空磁 力計や磁力傾度計・水中用扔よび陸上用重力計・各種の 坑井内検譄器・放射能拝よび地震探釷器たど実に扣びた だしい数に上っている。

カナダに揓いては, 米国と同様に活動昨が多く, 地 震・重力班はもとより航空磁全拉よび放射能理が大いに 活動している。アルバータ地方の珊瑚礁鉱麻に帰因する 大油田の発見は, 既によく知られているであろら。これ には米国の技術が直接につながっているのが注目され る。1951年に打いて多くの電磁探鉱が行わ水ているが6) これは僅少な経費で迅速に広大地域の踏査に用いられ5 る新しい調查方法として注目された。

ドイッ15? に扔いては 20 数班に招よぶ地震反射探査 斑, 数班の重力計班が活動して扔り, 新油田が発見され

14）飯田汲事： 物理探鉝第 3 巻第 3 号（1951）

15）香川貫一：石油技術協会誌第 16 巻第 6 号(1951)
ている。オランダに招いても成果があげられている。フ ランスに㨟いても地震探查に上る成果力゙注目されている し，イタリアでは多くの地域での地震反射法のほかに地 電流法分研究されている。英国に沏いて子地震班の活動 がある。アフリカに执いては数カ所に地震反射探鉱班の 活動があり，地震屈新・重力・磁気の各探鉱班もそ水ぞ れ活動している。な扔地電流法と電気探査法とが用いら れて, 成果の挙っているのが注目される。

南アメリカに招いては航空磁気法が適用されているほ か, 携带用の地震探鉱器に上る調査が英領西印度で兴施 され，立地条件の悪い油田地带の探査を能率的にし，成 功している。

印度に括いてはベンガル拈よびアッサム地方の㕕大な 油債平野に牧いて, 航空磁气法に上る調査が行われ, 油田 の開発に役立てられた。台湾その他東南アジア諸国に招 いても重力扣よび地震班の活動がみられたようである。

\section{4. 鉱山における物理探查}

わが国に怙ける鉱山調査の物理探鈗は，主として電気 扣よび磁気探鉱であるが，最近地震法る適用されて地質 構造・变質体・鈗休等の探査が行われ，また放射能や地 化学探鉣も実施されるにいたった。そして，いくつかの 探鉱法が併用されて，地質釷床の示寸物理的望象の解明 に精度がたかめられている。電気探鉱では自然電位法 (S. P. )・比抵抗法が主体であるが，最近流電電磁探鉣 法16) が研究されて, 実用へと発展しつつある。電気探 鈗の理論的研究17) は著しい発展を久て, 困難な問題解 渗に 1 歩前進したのだ, その研究の実際面への応用が期 待されている。実際的の研究方面もいろいろ進み, 実際 の現象解明に役立てられた。また方法として2極法や平 均 3 極法が研究され発展した。

各種鈗床の物理探釷資料の総括からその適灾性が論じ られえようになり，現場に扔ける調查技術や結果の解釈 に適切の度を加え，鈗床発見の確率を増大しつつある。 近年 (1348 年〜1951 年), 成果の挙げられた各種鉣床と 探鉱法を鉱山名とともに，主なるものについて示せば， 次のよらになる。

黒鉊 富山県千野谷釷山(電気) ・北海道音調津 鉣山(電気・磁気)

銅・硫化鉄 北海道余市鉱山(電気) ・青森県安部城鉱

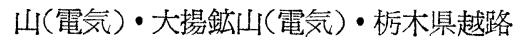
鉱山(電気) ・ 愛媛県大久喜鉱山(電気) ・

16）牧野直交・神代健夫・能谷昭一：物理探鉱 第 5 巻第 2 号 $(1952)$

17）清野武教授・前田活郎技官等の研究参照, 物理探 鏑第 3 巻 $(1950)$, 第 4 巻(1951)，第 5 巻(1952)等 


\author{
大分県㺵珠鉱山(電気，地震） \\ 秋田県明又鉱山・(電気) 同尾去沢鉱山 \\ $($ 電気) 同相内鉱山(電気) \\ 和歌山県妙法鉱山(電気) ・ 三重県紀州鉱 \\ • 山(電気) ・ 岡山県相原鉱山(電気) ・ 山口 \\ 県福重鋐山(電気・磁気) \\ 銅 - 鉄 福島県高倉鉱山(電気, 磁気) \\ 福島県八総鈗山(電気) ・ 秋田澋花岡鉣山 \\ (電気，地震）・山形県福舟鉣山(電気) \\ 鉄 \\ 硫 \\ 岩手県永石鉱山(磁気) ・岩手県和賀仙人 \\ 鈗山(電気) \\ 黄 山形県蔵王鉱山(電気) ・北海道精進川鉱 \\ 山(電気) ・岩手県松尾鈗山(電気) ・ 群馬 \\ 県吾妻鉱山(電気) ・同小串鉱山(電気) \\ マンガン 岩手県立川鉱山(電気)
}

以上は新たに鉱床が発見されたものであるがこれら のほか多くの示徵が得られ鉱山の開発に寄与されつつあ る鉣種としては，金鈗・鉊西鉛鉣・褐鉄鉣・石高・石灰 岩・クロ一ム鉄鉱・沼鉄鉱・水釭鉱・キースラガー・金 銀石英脈・重晶石・粘土等の各種があり，その適用範囲 が拡大されてきている。

探鉱器の進歩もまた著しく，高性能で小型化し，改良 型が実用に供されている。

米国に招いては, 航空機に上る磁気探鉱の発達によ り，広範囲の調查が汛速に行われる上らにたった。その 結果 1951 年にはペンシルバニア州グレイス鉱山におけ る1億噸以上にも扣上ぶ大鉱床の発見6)となりれはは約 $500 \mathrm{~m}$ の三畳䟕堆嘖物に覆われているが，既に開発され つつある。航空磁気探鉱には, ミネソタ州の北西扣上び 北東部・ニュージャーシイ州・カリフオルニア州・ワシ ントン州北酉部等各地に扔いて行われたが，ミネソタ 州の北東部のは，班励岩の分布状態上りその中に存する ニッヶル，銅の鉣化地带の発見に役立てるためのもので あり，ワシントン州に抢汁るものは高稼性の始新統溶岩 上にある新統堆蹟物の!構造探査に成功をおさめてい る。な打航空放射能喿釷特にシンチレーション・カウン ターによる調査も行われ，成果が挙っている。S.P法に よるアパラチア山胍附近の硫化鉣床の発見,ミン゙リー州 南東部の鉊鉱山地带での磁気・電気比抵抗・電磁気等の 探鉱法による鉊鈗床の発見，同州ワシントン郡の重力探 鉱による重晶石の鉱量探查, 此抵抗法によるケンタッキ 一州の脈状签石鉱の探鈗などがあり，カンサス州では蛇 紋岩の追跡が電気比抵抗法によって行われているし，コ ロラド州では同様な方法によって凹地堆積物の輪廓の決 定や破碎带の追跡が行われている。またアラスカで磁気 探鉱により，タングステン鉱鉱床の追跡が行わ水好結果
が得られている。

以上のほか新しい坑井内電気探鉱技術の進歩や，裂㱆 充填の岩脈または鉣脈の附近に抢ける母岩の残留歪及の 測定技術, 電気探鉱装置の改良, 特に大地抵抗測定器の ギッシュルーニー式整流子の代りに同調振動子を使用寸 る装置の考案など，種々の改良が行われている。

カナダに招いては，1951年に招ける鉱山調査の物理探 鈗は22昨に達し，そのらち主な発見はモガドル鉣山会社 の亜欽・鉛銀・鉱床である。また航空機によろシンチレー ション放射能探鉱により，チャルボア湖附近の放射能鉱 物を発見し，S.P法によりブリチッシコロンビア州バゼ ルトン地方の鉛・亜鉊・銀の鈗床や，ヶベック州の西部 扣よびオンタリオ州の東部に猢る硫化鉱休の調査が行 われている。生物地化学探査がブリチッシコロンビア州 の鉱山会社で行わ扎，鉱床調査に利用面を開いている。

欧州6)では，まずスェーデン北部に招いて航空磁気探 鉱に上り幾っかの磁鉄鉱々床が探査され，西ドイッでは 地震探鉱が鉱床発見に利用されている。フランスではブ ルターニュ半島の鉄鉱床に対する電気招よび磁気探鉱が ありイイタリアでは S.P 法により黄鉄鉱々洙の調查が パザノ附近で行わ水ている。な拁，ソ連に㧊いて子航空 磁気探鉱などが行われているよらどもるが，詳細は不明 である。

アフリカに招いては, 電気探鉱によりダイヤモンドの 探查や S.P.法による銅鉱床の探查が有効となっている。

印度に扣いては, 磁気操鉱によりシャルボーン附近の クロマイト鉄釷の調査が行われ，その適用性が明らかに されたっ またバンテックス附近のマンガン鉱带の沖箐地 にも行わ机, バタグハット地方の磁気探鉱の結果により, 浅所に極めて多くの小マンガン鉱体の女るのが発見され た。な扔磁気・電気両探鉱にて銅鉱床の地带の調査に成 果が得られている。

\section{5. 地下水・基盤その他に応用された物理探查}

わが国に掂いては，土木方面の物理探査は 1931 年頃 から行われているが，主として地震と電気の方法が活用 され，幾多の成果が発表されている。現在医堤基盤・㯌 道地盤・橋梁地船・地之地带・破砾带・空洞・断層等の 各種の探査に応用されているが，地下の極めて浅い所の 探査であるだけに試錐による確認が容易であり，その成 果が淔ちに判明する場合が多い関係上，その結果の精度 の高いもの要求されて抢り, 必然的に, 調査方法气の他 に関して，この分野独特の発展がある。天龍川・利根川 等の水系に打注電源開発用ダムの基盤調査を初め, 全

18）佐藤光之助：物理探釷第 2 巻第 2 号（1949） 
国各地に狲て物理探查が活用されている。た打地盤の 調查には, 器械的に地面に振動を与兄る動力学的方法も 発展している19)。

地下水関係の物理探査は 1934 年頃から行われている が, 最近持に農業用開拓用水や工業用水方面の調査が多 く行われるよらにたり, 著しく利用範囲が拡大された。 電気探査が主体であるが，地震拈查るまた行われてい る。全国各地に括いて著しい成果が挙げられて抢り, 伏 流水の位置・带水層の梁度や籍囲などが明らかにされて いる。な扔坑井内探査も行わ扎ている。

温泉の探査には電気探査のほか, 放射能・地温・地化 学等の探查法も用いられ, 四国の道後温泉・九州の別府 温泉付近等の調査をはじめ, 幾多の好結果が報告されて いて,この方面への発展がみられた。最近地熱発電の対 象として地熱の調查が浮び上ってきたが，電気・重力・ 放射能・地温・地化学等の探查法によって解明されつつ ある。北九重山周辺20) との他温泉地带に挌いては地 熱による変質带の探查は有効であったから, 今後この方 面の研究も期待されるであらら。

地盤の良否に関連して天然地震による災害の問題が論 じられているが,この目的のために都会地を中心として 地盤の探查21) が行われ，その効果が明らかにされてい る。な扣古㩌の探查に電気や磁気の方法が応用されて, 神奈川目・東京都等に括いて多数の古代住居が発見され， その探查の有効性が明らかにされている22)。

欧米諸国の近況6)を久るに，まず米国においては，地 下水や基盤の調查に物理滐査主として地震拈よび電気探 査法が用いられ, 多くの成果が発表されている。ニニー ヨーク州のダム建設予定地の基盤の電気探査, セントル イスに淤ける基盤の電気扔よび地震法に上る探查等は試 錐に上り確認されてその成果が判明し，オハイオ・カリ フォルニア・ニューヨーク拈よびアイダホ等の州では地 下水の調查に地震扔よび比抵抗法の探查が行われて成功 しているほか, メノミニ一地方の主要地下構造の探查に は重力法が用いられている。各地に㨟いて主要土木事業 を行ら地带には物理探查が行われて, 基盤までの断面が 決定されているので, この方面に招汁万発曼の程度も5 かがえるで女ろう。

カナダに抬いては, オンタリオ附近に扔计る幾多のダ 么の基盤調查に比抵航法の成果が報告されている。

欧州に扔いては, まずフランスでは東部の沖債平原地 带に抬ける地下水の調査に電気探相を活用して扔り,イ

19）鈴木武夫技師等の調查による。

20 ）下河原達哉・陶山淳治等の 1951 年の調査に上る

21）表 俊一郎 - 神田祐太郎：物理探鋝第 2 巻第 2 号 (1938)

22）藤井鹿三郎教授等の 1951 年の調査による。
タリアでは, 地下水の電気探查のほか, カンピ・フレグ りの火山地方に呿いて比抵抗法が地熱エネルギーとして 利用される高温蒸気の探查に用いられている。ラルデレ ルロでは自然の蒸気に対する電気探查が高度の成功を括 さめ，地下数 $100 \mathrm{~m}$ に対しても有效とのことどある。ま たスペインでは電気怙よび重力探査に上り, 伏流水の径 路が発見されている。

アイスランドては温泉源選定に物理探査を適用して成 功している。

アフリカでは, 仏領モロッコ・西部アフリカ・南ロー デシァその他に捻いて地下水の探査が比抵抗泿によって 行われて扣り, ニュージーランドでは, 水力発電の可能 性が制限を受けているので, 地熱蒸気からの発電の問題 を物理探查を利用して解決しょらとして招り, 地化学探 查をも用いている。な拸くの火山地方に招いては航空 機に上る磁気探査や重力・地震・電気・放射能等の探査 資料が得られていると報告されている。

印度では，ビハール州に゙の基盤の探査が地震屈折法・ 電気此抵抗法に゙成功を招さめている。

\section{6. 結 語}

物理探査は各種の方法と各種の応用対象がもり, 各分 野においてそれぞれ未解決の問題が山積しているが, 最 近漸く学問としての体系ができつつあり,Coal and Petroleum Exploration Geophysics, Mining Explora"tion Gephysics, Engineering Exploration Geophysics として発展の途上にある。他の学問技術の進歩と相 末って, 以上述べたよらに進展してきたが, 今後の発展 がさらに一段と期待されるわけである。本交は主として 1951年を中心として論じたものであり，その進歩が日進 月歩である今日多少の脱落はあろ万かと思われるが, 紙 面の許寸限り大体それを書きしるした積りである。

何はともあれ，米国に扔ける物理探査は，ハンマー博 士の言を借りるまでもなく, 成年の域に達して基濋が確 立した今日，その上での今後の発展がさらに目覚しいる のがあるであろ5。米国の物理探鉱学会は1930年の設立 になり, 既に 20 余年を経過し現在 3,000 人以上の会員 をようして活動しているが，わが国に招いては約 5 年前 の1948年に至って漸く学会の創設をみ, 現在的 600 名の 会員をよらして活動しているにすぎない。しかしながら， こつ上う子学会つ没立头来, 各方面の人たちの意志の 交換や研究の発表が行わ扎るようになり, 物理探査の発 展间上にその足跡がみら机るよらになったことは喜ばし い次第である。このような情勢下に执いて, 各方面各位 の御援助御協力をえて, ますますわが国の物理探查を発 展せしめたいと念願してやまない次第である。 